\title{
Judicial Review of the Legislative Process in Lesotho: Lessons from South Africa
}

H 'Nyane*

\section{P.E.R}

Pioneer in peer-reviewed, open access online law publications

Author

Hoolo 'Nyane

Affiliation

University of Limpopo

South Africa

Email hoolo.nyane@ul.ac.za

Date Submission

26 October 2018

Date Revised

20 September 2019

Date Accepted

20 September 2019

Date published

18 October 2019

Editor Prof A Agbor

How to cite

'Nyane $\mathrm{H}$ "Judicial Review of the Legislative Process in Lesotho: Lessons from South Africa" PER / PELJ 2019(22) - DOI http://dx.doi.org/10.17159/17273781/2019/v22i0a5713

Copyright

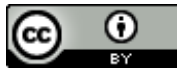

DOI

http://dx.doi.org/10.17159/17273781/2019/v22i0a5713

\begin{abstract}
The Constitution of Lesotho, 1993 has a supremacy clause which ordinarily empowers the judiciary to review the actions of other branches of government. However, the judiciary in Lesotho seems to treat the legislative process with deference. This deference seems to be based on the old common law notion of the non-intervention of the judiciary in the legislative process. The notion has its roots in the British constitutional system. The Constitution of Lesotho has even protected this doctrine through a constitutional ouster clause in section 80(5). The main question which this paper seeks to answer is whether indeed the common law notion of non-intervention in the legislative process is part of the constitutional law of Lesotho. In the end, the paper uses South African jurisprudence on the review of the legislative process to make a case that Lesotho can use the supremacy clause in the constitution and other constitutional doctrines such as the rule of law and legality to break with the common law notion of non-interventionism.
\end{abstract}

\section{Keywords}

Lesotho; Constitution of Lesotho; judicial review; legislative process; South Africa. 


\section{Introduction}

The Constitution of Lesotho, 1993 like the Constitution of the Republic of South Africa, 1996 cherishes the notion of constitutional supremacy. ${ }^{1}$ That notwithstanding, the notion exists against the strong backdrop of the Britishbased design of the institutions of government. Consequently, British constitutional theory undergirds constitutional design in Lesotho. ${ }^{2}$ Despite the many influences that the South African law has had on Lesotho law generally, ${ }^{3}$ constitutional law - due to the strong English influence - remains defiant. One of the areas which remains faithful to the English concept of inter-branch relationship is the review of parliamentary work in general, and the legislative process in particular, by the courts of law. ${ }^{4}$ The English law is almost settled, and it has been widely exported to the broader commonwealth family of constitutions, ${ }^{5}$ that due to the time-honoured doctrine of parliamentary sovereignty, the work of parliament may not be vitiated by any authority; not even by a court of law. This rule has been the subject of long and sometimes contradictory scholarly and judicial engagement. ${ }^{6}$ However, the classical analysis of it remains that of the British scholar, Dicey. ${ }^{7}$ In his formulation, the notion of parliamentary sovereignty involves three "traits". The first one is the omnipotence of parliament; "the power of the legislature to alter any law, fundamental or otherwise, as freely and in the same manner as other laws". ${ }^{8}$ The second one is that there is one corpus of law. The idea of having a distinction

Hoolo 'Nyane. LLB (Lesotho) LLM (NWU) LLD (UNISA). Associate Professor and Head of Public and Environmental Law Department, School of Law, University of Limpopo, South Africa. E-mail: hoolo.nyane@ul.ac.za.

1 Section 2 of the Constitution of Lesotho, 1993 (hereafter Constitution of Lesotho) provides that "[t] his Constitution is the supreme law of Lesotho and if any other law is inconsistent with this Constitution, that other law shall, to the extent of the inconsistency, be void". The supremacy clause in the Constitution of the Republic of South Africa, 1996 (hereafter the South African Constitution) is embodied under s 2 too. The legal effect of constitutional supremacy has been the subject of several formative judgements, to wit; In re Certification of South Africa 19964 SA 744 (CC); $S$ v Makwanyane 19956 BCLR 665 (CC); Executive Council of the Western Cape Legislature $v$ President of the Republic of South Africa 199510 BCLR 1289 (CC).

2 See Palmer and Poulter Legal System of Lesotho 223; 'Nyane "Development of the Constitution of Lesotho" 121; 'Nyane 2014 Lesotho LJ 59.

3 Lesotho shares the Roman-Dutch common law with South Africa. See Beardsley 1970 J Afr L 198; Palmer 1969 J Afr L 127. However, the development of common law in South Africa is much more advanced than in Lesotho, and Lesotho depends disproportionately on advancements in South Africa.

4 See s 80(1) of the Constitution of Lesotho. The section is the mirror-image of s 2(1) of the United Kingdom Parliament Act of 1911 as amended in 1949 by United Kingdom Parliament Act of 1949.

5 De Smith New Commonwealth and its Constitutions 543.

$6 \quad$ Goldsworthy Parliamentary Sovereignty 30; Delaney 2013 Nw U L Rev 543; Barber 2011 ICON 144; Tucker 2011 OJLS 72.

$7 \quad$ Dicey Study of the Law of the Constitution ch II.

$8 \quad$ Dicey Study of the Law of the Constitution 83. 
between constitutional law and other ordinary law, so that the former becomes the "higher law", is alien to the classical English design. He posited that: ${ }^{9}$

There is under the English constitution no marked or clear distinction between laws which are not fundamental or constitutional and laws which are fundamental or constitutional.

The third one, which is more closely related to the subject under investigation here, is the non-reviewability of parliament; "the non-existence of any judicial or other authority having the right to nullify an Act of Parliament, or to treat it as void or unconstitutional". ${ }^{10}$ In terms of this tenet, the work of parliament is immune to review and sacrosanct, whether substantively or procedurally.

Whether this classic formulation is or has ever been part of Lesotho's constitutional law is a matter of controversy; regard being had to the fact that Lesotho has always had a written constitution since independence in 1966 - even prior to that date ${ }^{11}$ - which embodied the supremacy clause. ${ }^{12}$ The judicial attitude is divided on this aspect. In the case of Khaketla $v$ Honourable Prime Minister, ${ }^{13}$ which was decided in 1985 when the Constitution was still suspended, ${ }^{14}$ the court declined to nullify the law, citing the doctrine of parliamentary sovereignty. In a similar manner, the court in the case of Tsang $v$ Minister of Foreign Affairs ${ }^{15}$ reiterated the position in the Khaketla case. But the Court of Appeal, in a much more convincing decision in the case of Attorney General $v$ Swissbourgh Diamond Mine, ${ }^{16}$ confirmed the finding of the High Court that parliamentary sovereignty, at least in its classical formulation, is not part of Lesotho's constitutional law. As a result of this decision, the courts in Lesotho have declared certain pieces of legislation unconstitutional with relative ease. ${ }^{17}$ Whilst they are now almost comfortable with the substantive review of parliament and the

$9 \quad$ Dicey Study of the Law of the Constitution 85.

10 Dicey Study of the Law of the Constitution 85.

11 See the Basutoland Constitutions of 1959 and 1965.

12 Section 2 of the Lesotho Constitution of 1966 embodied the supremacy clause.

13 Khaketla v The Honourable Prime Minister (CIV/APN/145/85) [1985] LSCA 118 (24 July 1985) (hereafter the Khaketla case).

14 The 1966 Constitution of Lesotho was suspended in 1970. For the detail on the suspension of that Constitution, see Khaketla Lesotho 1970 103; Macartney 1973 Government and Change 473.

15 Tsang $v$ Minister of Foreign Affairs 1993-94 LLR-LB 45 (HC) (hereafter the Tsang case).

16 Attorney General $v$ Swissbourgh Diamond Mine LAC (1995-99) 214 (hereafter the Swissbourgh Diamond Mine case).

17 See Attorney General v Mopa LAC (2000-2004) 427; Peta v Minister of Law, Constitutional Affairs and Human Rights (CC 11/2016) [2018] LSHC 3 (18 May 2018). 
review of administrative decisions, ${ }^{18}$ the review of a legislative process continues to be unsettled. The question is further complicated by the Constitution, which makes the parliament a master of its own procedure. ${ }^{19}$ The same Constitution compounds the matter even further by capping it with an ouster clause; that once the Speaker of parliament has certified that the procedure for enacting any piece of legislation has been followed, such certification may not be questioned in any court of law.

As such, the question of whether a court of law can review the legislative process in Lesotho continues to haunt constitutional scholarship in the country. Much as the question is relatively settled in South Africa, the courts in Lesotho seem to take a deferential approach to the question. ${ }^{20}$ Influenced by the common law non-interventionist approach to the internal legislative process, and the tapestry of the Constitution of Lesotho, the courts seem to respect the parliament as it relates to the internal affairs of parliament.

Hence, the purpose of this paper is to denounce this approach as being contrary to the broader schematisation of the Constitution of Lesotho anchored by the devices of constitutionalism such as the rule of law, legality, the separation of powers and, indeed, the hallowed notion of the independence of the judiciary. The paper uses some lessons from South Africa, where the judiciary has unequivocally jettisoned the notion of parliamentary privilege and has employed devices such as legality and the rule of law to justify its unrestrained intervention in the so-called "internal affairs" of parliament. The paper methodically scrutinises decided cases in Lesotho and South Africa in the context of the broader constitutional designs of each country. The usual caution that accompanies comparative constitutional studies is issued, that one should not blindly presume that South African constitutional jurisprudence can be transplanted mutatis mutandis into Lesotho. The paper starts off by re-problematising the theory on which the review of the legislative process is based, and proceeds to

18 Chalatse $v$ The Acting Chief Justice (C of A CIV NO/63/2014) [2015] LSCA 19 (7 August 2015); Raphuthing $v$ Chairman of the Disciplinary Hearing $C$ of A (CIV) 45/2014 [2015] LSCA 2 (7 August 2015).

19 See s 80(5) of the Constitution. Also see Lesotho Constitutional Court decision in Transformation Resource Centre $v$ Speaker of the National Assembly (Constitutional Case No 4 of 2017) [2017] LSHC 23 (30 November 2017) (hereafter the Transformation Resource Centre case).

20 In the Transformation Resource Centre case paras 20 and 21, the court said, "This brings me to [applicants'] second proposition ... that the Standing Orders of the National Assembly ... provide for peremptory procedural requirement for public participation... . It rests on the fallacy that the internal rules of parliament made pursuant to section 81(1) have constitutional force and, therefore any irregularity in following them is violation of a peremptory constitutional procedure. This proposition raises issues which have implication for the separation of powers and the jurisdiction of courts to enforce internal rules of parliament." 
study the judicial approaches to the review of the legislative process in each of the two countries under study herein.

\section{Revisiting the theories of judicial review of legislative process}

\subsection{Demarcation of judicial review of legislative process}

Judicial review as a device used by courts to supervise administrative, executive or judicial actions has become a very complex notion which takes various forms. ${ }^{21}$ Whatever form it takes, the notion of judicial review still depends on the broader constitutional design of a country. In relation to judicial review, countries fall into two loose families - the Westminster family and the American family. The Westminster models follow the predominantly "weak" judicial review system, due in large part to their notion of parliamentary sovereignty, ${ }^{22}$ which is known for its animosity towards any form of check on the power of parliament which, in those designs, permeates almost all aspects of governmental power. It is adroitly captured by Allan and Thomson thus: ${ }^{23}$

In some countries ... the judges are permitted to review legislation in order to establish whether it complies with the ... constitution. In the United Kingdom, the absence of a written constitution with the status of a high law and the doctrine of parliamentary supremacy prevent the judge from exercising this role.

In the Westminster-based model the court's power of review is limited to the way in which the power conferred by parliament is exercised, otherwise known as the doctrine of ultra vires. ${ }^{24}$ That is basically judicial review in the

$21 \quad$ Hoexter Administrative Law 109.

22 Harel and Shinar 2012 ICON 950. At 952 and 953 the authors contend that jurisdictions including the UK, Canada, New Zealand, and several states and territories of Australia have adopted schemes that can be characterised as forms of constrained judicial review, and on the other hand they argue that in the American style, "judicial review [is] also known as strong judicial review. Under that view, the judiciary is the 'ultimate expositor' of constitutional meaning, having the final say over constitutional interpretation". Also see Arenson 1996 Deakin L Rev 37.

$23 \quad$ Allen and Thomson Cases and Materials 541.

24 See Johannesburg Consolidated Investment Co v Johannesburg Town Council 1903 TS 111. The overriding justification for judicial intervention is the doctrine of ultra vires - the doctrine that power (vires) must be exercised within the confines of the law set out by parliament. As Hoexter pointedly contends at 111 , "The doctrine ... is tied to constitutional fundamentals associated with the Westminster system: separation of powers, parliamentary sovereignty and the rule of law .... The legislature is the supreme lawmaker, while the function of the courts is to apply the law made by it". 
administrative-law sense; "the power of the courts to scrutinise and set aside administrative decisions on the basis of certain grounds". ${ }^{25}$

Judicial review in the constitutional designs that follow the American model adopts a somewhat different approach. Since the decision in Marbury $v$ Madison, ${ }^{26}$ the American model of judicial review has been growing rapidly, to the extent that it has even taken on the form of being a threat to majoritarianism. ${ }^{27}$ Some scholars have even dared to call it the basis for "judicial supremacy". ${ }^{28}$ The American model is anchored on "strong review"; that "the judiciary is the 'ultimate expositor' of constitutional meaning, having the final say over constitutional interpretation". ${ }^{29}$

Nevertheless, despite these marked differences in the models of judicial review in the Westminster and American models, there seem to be some commonalities when it comes to the judicial review of the legislative process. The review of the legislative process is different from substantive review in that the latter is by and large concerned with the compliance of the legislation with the Constitution. ${ }^{30}$ Many a time, substantive review has to do with the question of whether a certain constitutional norm has been violated; invariably whether a "certain statute infringes upon individual liberties or rights guaranteed in the Bill of Rights". ${ }^{31}$ It is less concerned about the propriety of the process that was followed in enacting the statute in question. It differs from procedural review in that procedural review is a "form of judicial review in which courts: either a) determine the validity of statutes based on an examination of the procedure leading to their enactment; or b) oversee the adherence to procedural rules whilst the legislative process is going on."32

In this aspect of process there is similarity between the Westminster and American models. Both of them, albeit to varying degrees, accord some measure of deference to the internal processes of parliament. The courts are, as a general rule, not expected to interfere with the internal processes of parliament, even when there is an allegation of impropriety or illegality. ${ }^{33}$

$25 \quad$ Hoexter Administrative Law 109.

$26 \quad$ Marbury v Madison 5 US (1 Cranch) 137 (1803).

27 Waldron 2006 Yale LJ 1346. Bickel Least Dangerous Branch 16-17 contends that, "[J]udicial review is a counter-majoritarian force in our system. ... [W] hen the Supreme Court declares unconstitutional a legislative act ... it thwarts the will of representatives of the actual people of the here and now ...."

Harel and Shinar 2012 ICON 950.

Harel and Shinar 2012 ICON 953.

Bar-Siman-Tov 2011 BU L Rev 1915.

Bar-Siman-Tov 2011 BU L Rev 1923.

Bar-Siman-Tov 2011 BU L Rev 1921.

The point was made rather succinctly and poetically in the case of British Railways Board v Pickin [1974] 1 All ER 609622 as thus, "It must surely be for Parliament to lay down the procedures which are to be followed before a bill can become an Act. 
This non-interventionist approach has dominated the court-parliament relationship in both models since time immemorial. However, some modifications are beginning to be introduced in countries like South Africa, where it has been argued that a court of law may intervene in the internal affairs of parliament on the basis of the ascendency of the notion of legality.

\subsection{The origins and rationale for non-interventionism}

The protection of parliamentary privilege is, like most devices of modern day parliamentary practice, a by-product of the sixteenth and seventeenth century struggles between parliament and the crown in England. ${ }^{34}$ Privilege is classically a composite concept which protects not only the speeches of members of parliament but also the internal proceedings of parliament. ${ }^{35}$ Privilege originated in the sad practice in England whereby the King used to have informers about the proceedings of parliament and the speeches of individual members of parliament, after which those members of parliament who were against the King were targeted with prosecutions and other forms of assaults because of what they had said or done in parliament. The zenith of this struggle between the Tudors and the Crown on the one hand and the House of Commons on the other occurred in 1512 during the case of Richard Strode. ${ }^{36}$ This was the case in which Richard Strode, a member of the House of Commons, introduced a series of Bills that were regarded as offensive to the reigning King Henry VIII. ${ }^{37} \mathrm{He}$ was prosecuted and a heavy fine and imprisonment were imposed on him. The House of Commons was particularly displeased with what happened to Strode and retaliated by enacting the law that became the turning point, and arguably the basis for the notion of parliamentary privilege as it is understood today in parliamentary practice throughout the world. The law annulled and invalidated the Court's decision on Strode. It provided emphatically, and in a rather ad hominem manner, that: ${ }^{38}$

It must be for Parliament to decide whether its decreed procedures have in fact been followed. It must be for Parliament to lay down and to construe its standing orders and further to decide whether they have been obeyed; it must be for Parliament to decide whether in any particular case to dispense with compliance with such orders. It must be for Parliament to decide whether it is satisfied that an Act should be passed in the form and with the wording set out in the Act. It must be for Parliament to decide what documentary material or testimony it requires and the extent to which Parliamentary privilege should attach. It would be impracticable and undesirable for the High Court of Justice to embark on an enquiry concerning the effect or the effectiveness of the internal procedures in the High Court of Parliament or an enquiry into whether in any particular case those procedures were effectively followed." Salva 1963 Philip LJ 477; May Erskine May's Treatise 48; Steele 2012 Nott LJ 43. May Erskine May's Treatise 48. Yankwich 1950 U Pa L Rev 960; Cella 1968 Suffolk U L Rev 1. Salva 1963 Philip LJ 477. Hatsell Precedents of Proceedings in the House of Commons 86. 


\begin{abstract}
All suits, condemnations, executions, fine, amerciaments, punishments, connections, grants, charge, and impositions, put or had, or hereafter to be put or had, upon the said Richard, and to every other person or persons afore specified, that now be of this present Parliament, or that of any Parliament, thereafter shall be, for any Bill, speaking, reasoning, or declaring of any matter or matters concerning the Parliament, to be communed and treated or, be utterly void and of none effect.
\end{abstract}

Although the law was ad hominem and retroactive in nature, it also established the rule for the future relationship between parliament and the courts in relation to the internal proceedings of parliament. Nevertheless, despite this definite declaration of privilege, the struggles between parliament and the Crown never abated. In the person of the sovereign, the Crown was still hugely interested in the internal proceedings of parliament.. Parliament finally triumphed over the monarch after the Revolution of 1688. ${ }^{39}$ Through the Bill of Rights (1689), the privilege of parliament was sealed through absolute immunisation. The Bill of Rights provided that "the freedom of speech, and debate or proceedings in Parliament, ought not to be impeached or questioned in any court or place out of Parliament."40

In the United States, privilege was received through the doctrine of "enrolled bill" in the case of Field $v$ Clark. ${ }^{41}$ This case established that in accordance with the principle of privilege of parliament provided in the English Bill of Rights (1689), the signature of the Speaker of the House of Representatives on an "enrolled bill" was conclusive evidence that the Bill had been properly passed, and it might not be called into question or impeached in the courts of law. It was not proper to inquire into the journals of parliament to inquire whether or not the Bill had been properly passed.

It is apparent that the privilege of parliament has developed from its classical beginnings, where it was intended to shield parliament and its members against the Crown. It has grown in its scope and purpose to the stage where today it is protecting members of parliament not only against the monarch or executive, but even against everyone else. ${ }^{42}$

While the original rationale for privilege was to protect parliament and its members against unscrupulous monarchs in England, the notion has acquired many different purposes over time. ${ }^{43}$ Okpaluba articulates six justifications for the non-intervention of the courts in internal parliamentary

$39 \quad$ Bradley and Ewing Constitutional and Administrative Law 54-57.

40 Bill of Rights (1689). The principle was to be reiterated in later cases in England, such as Edinburgh \& Dalkeith Railway v Wauchope (1842) $8 \mathrm{Cl}$ and F710 725; Lee v Bude \&Torrington Railway Co 1871 LR 6 CP 577.

$41 \quad$ Field v Clark 143 US 649 (1892).

42 Yankwich 1950 U Pa L Rev 960.

43 See Andrews Works of James Wilson quoted in Okpaluba 2015 CILSA 188. 
processes. ${ }^{44}$ They are: a) immunity against prosecution: protection against possible prosecution by an unfriendly executive and conviction by a hostile judiciary; b) immunity from deterrents to the uninhibited discharge of their legislative duty; c) the independence of parliament: the legislature as a key organ of democratic government ought to enjoy absolute independence from outside interference or control; d) the smooth management of parliament: appeals to the courts as to whether the behaviour of a member of the legislature does or does not merit a particular sanction would impair the proper functioning of the chamber by enmeshing it in legal proceedings; e) reciprocity: judicial abstention from interference in parliamentary proceedings guarantees parliamentary abstention from interference in the judicial process; and f) the availability of remedies: a legislature could provide its own remedies for injustice perpetrated against a member by itself or its officers. A member who is dissatisfied with internal decisions can appeal to the voters. ${ }^{45}$

These justifications can be collapsed into two main rationales for parliamentary privilege. The first one is the protection of the freedom of members and the house of parliament from external interference and inhibition. The second one is the hackneyed principle of the separation of powers. Both of these two main justifications are in synch with contemporary concepts of the freedom of speech ${ }^{46}$ and the separation of powers. ${ }^{47}$

\subsection{The "new approach": a departure from non-interventionism}

Despite its antiquity and justification, ${ }^{48}$ the notion of parliamentary privilege is showing some signs of attenuation from its classical form, in which the protection was absolute, into a "new model" based on a sensitive balance between legality on the one hand and the separation of powers on the other. ${ }^{49}$ This new approach represents a marked departure from the absolute immunity that parliament used to enjoy in its internal proceedings. It is best represented by the dictum of the Constitutional Court of South

\footnotetext{
$44 \quad$ Okpaluba 2015 CILSA 183.

45 Okpaluba 2015 CILSA 192.

46 See the cases of Speaker of the National Assembly v De Lille 19994 SA 863 (SCA) (hereafter the De Lille case); Mazibuko v Sisulu 201311 BCLR 1297 (CC) (hereafter the Mazibuko case).

47 Doctors for Life International v Speaker of the National Assembly 20066 SA 416 (CC) (hereafter Doctors for Life International case).

$48 \quad$ Okpaluba 2015 CILSA 190; Sakoane 2000 Lesotho LJ 39.

49 Kretzmer 1988 Tel Aviv U Stud L 95; Navot 2006 Israel L Rev 183.
} 


\section{Africa in the case of President of the Republic of South Africa $v$ United Democratic Movement, ${ }^{50}$ thus: ${ }^{51}$}

Having regard to the importance of the Legislature in a democracy and the deference to which it is entitled from the other branches of government, it would not be in the interests of justice for a Court to interfere with its will unless it is absolutely necessary to avoid likely irreparable harm and then only in the least intrusive manner possible with due regard to the interests of others who might be affected by the impugned legislation. Where the legislation amends the Constitution and has thus achieved the special support required by the Constitution, Courts should be all the more astute not to thwart the will of the Legislature save in extreme cases.

However, it should be noted that the nature of this new approach is far from being clear, as scholars and judiciaries are continuing to grapple with its true nature. ${ }^{52}$ Flashes of this new approach are flickering in the majority of jurisdictions, ${ }^{53}$ but they are arguably brightest in the United States of

President of the Republic of South Africa v United Democratic Movement 20031 SA 472 (CC) (hereafter the UDM case).

51 See the UDM case para 31. It would seem that the approach suggested in casu is that as a general rule, a court will be slow to intervene in the internal proceedings of parliament. The courts may intervene in "extreme cases", however. Also see Okpaluba and Mhango 2017 LDD 1. This approach also became evident in the Israeli Supreme Court Decision in the case of Sarid v Knesset Speaker (1981) 36 (2) PD 198. This was the case in which the Speaker of the Knesset (parliament) had changed the times for the sitting of the house from $11 \mathrm{am}$ to $5 \mathrm{am}$. An opposition member had tabled the motion of no confidence in the House, expecting it to be deliberated and be voted upon, in the morning, as was the tradition. However, it transpired that most members of House allied to government were travelling and could be available only late in the afternoon. As a result, the Speaker postponed the sitting to late in the afternoon. The decision of the Speaker was challenged. The Speaker's defence was that the decision was part of the internal affairs of parliament and thus non-justiciable. The Court agreed but observed at para 9 that, "It seems ... that these opposing considerations of the rule of law, on the one hand, and respect for the Knesset's special standing on the other hand, require a judicial balance, which is based on restraint, yet does not yield to complete impotence. This self-restraint must be based on a standard which will define those areas in which the court will not interfere out of respect for the uniqueness of the Knesset as the people's elected body, and those in which the court will intervene to preserve the rule of law in the legislature."

52 In the Economic Freedom Fighters $v$ Speaker of the National Assembly 20163 SA 580 (CC) (hereafter called EFF I case) para 93, the court attempted, but in vain, to provide some guidelines on the "new approach" thus, "It falls outside the parameters of judicial authority to prescribe to the National Assembly ... what mechanisms to establish and which mandate to give them, for the purpose of holding the Executive accountable and fulfilling its oversight role of the Executive or organs of State in general. The mechanics of how to go about fulfilling these constitutional obligations is a discretionary matter best left to the National Assembly. Ours is a much broader and less intrusive role. And that is to determine whether what the National Assembly did does in substance and in reality amount to fulfilment of its constitutional obligations. That is the sum total of the constitutionally permissible judicial enquiry to be embarked upon".

$53 \quad$ For Brazil, see Barroso da Graca 2018 UCL JL and J55; for Nigeria see Taiwo 2009 Malawi LJ 236; in relation to India see Jain 1967 JILI 205, who contends that, "[o]ur 
America and South Africa. The United States started to punch some holes earlier in the doctrine of "an enrolled bill", which was entrenched in the jurisprudence of that country, in the case of Field $v$ Clark. ${ }^{54}$ The essence of the new approach is that the internal processes of parliament should still be respected, as parliament is a co-equal branch of government, but the courts should intervene when the process by which a law is enacted violates the procedure laid out by the Constitution or in some other law. The prime example of the adoption of this approach is the US Supreme Court decision in the case of Powell v McCormack. ${ }^{55}$ This was a case in which the petitioner was elected to serve in the United States House of Representatives for the 19th Congress. However, the Congress passed a resolution that due to his financial misconduct in the preceding Congress he would not be allowed to sit as a member in the new Congress. He challenged his being disbarred on the ground that it violated Article 1 of the Constitution. The court found that the Constitution provided the requirements for the eligibility of people to be elected to congress - namely, age, citizenship, and residence. Thus, Congress had no power to exclude a person from sitting as a member of congress. ${ }^{56}$

It is now almost settled that when parliament violates internal procedures laid out by the Constitution itself, the courts will intervene. However, in this new approach the courts are battling with the sensitive balance of respecting parliament but at the same time checking that parliament complies with the law relating to its own internal affairs. ${ }^{57}$ This challenge, as

legislatures have undoubtedly plenary powers. But these powers are controlled by the basic concepts of the written Constitution itself which is supreme and sovereign. Therefore, there can be no doubt that the sovereignty which can be claimed by the Parliament in England, cannot be claimed by any legislature in India".

$54 \quad$ Field $v$ Clark 143 US 649 (1892). And the rule has been fairly established in the US. See the decisions in Dombrowski v Eastland, 387 US 82 (1967); United States v Johnson 383 US 169 (1966); Tenney v Brandhove 341 US 367 (1951); and Kilbourn $v$ Thompson 103 US 168 (1881) (hereafter the Kilbourn case).

55 Powell v McCormack 395 US 486 (1969).

56 The Court at 199 quoted with approval the dictum from the Kilbourn case, thus: "[e]specially is it competent and proper for this court to consider whether its [the legislature's] proceedings are in conformity with the Constitution and laws because, living under a written constitution, no branch or department of the government is supreme, and it is the province and duty of the judicial department to determine, in cases regularly brought before them, whether the powers of any branch of the government, and even those of the legislature in the enactment of laws, have been exercised in conformity to the Constitution, and, if they have not, to treat their acts as null and void".

$57 \quad$ See the Supreme Court of Israel decision in Sarid v Knesset Speaker (1981) 36 (2) PD 198 203. The court said: "It seems to me that the clash of the said values of rule of law, on the one hand, and respect for the unique character of the Knesset, on the other, require forging a judicial balance based on self-restraint of the judiciary, which does not amount to being totally bound." 
will more fully be demonstrated later in this paper, is more pronounced in South Africa.

\title{
3 Judicial review of the legislative process in Lesotho
}

The parliamentary procedures in Lesotho are based on the British model of parliamentary practice. ${ }^{58}$ As one commentator accurately commented, writing about its similarity to the British model: 59

\begin{abstract}
Certainly the physical pattern is that of Westminster, down to the dispatch boxes presented by the British House of Commons and the Gentleman Usher of the Black Rod, who looks just as much the part as does his British namesake. In its anxiety not to deviate from British parliamentary practice indeed the National Assembly is officially converted into an upper house for the Speech from the Throne by the simple expedient of a ritual draping of the Speaker's chair with royal purple.
\end{abstract}

The general reticence of Lesotho's judiciary to review the legislative work of parliament started prior to the 1993 Constitution, when the courts almost invariably declined to exercise either substantive or procedural review. The maiden case of this approach was the case of Khaketla $v$ The Honourable Prime Minister. ${ }^{60}$ The case arose out of the run-up to the much derided 1985 election. ${ }^{61}$ In casu, with a view to minimising the participation of the opposition, the government amended the electoral law to increase both the number of people required for the endorsement of a candidate and the fee for the registration of a candidate. ${ }^{62}$ The applicant challenged the law on the basis, amongst others, that it violated the right to vote and to be voted for, as enshrined in the Human Rights Act. ${ }^{63}$ The court frowned upon such a prayer and remarked that in terms of Lesotho's constitutional law "however unjust, arbitrary or inconvenient any legislation may be, it must be given its full effect. It is not the province of the Court to scan its wisdom or policy and the Court must take the statute as it finds it". ${ }^{64}$ This approach was replicated in the 1992 decision of the High Court in the case of Tsang $v$ Minister of

$58 \quad$ Palmer and Poulter Legal System of Lesotho 305-316. In the case of Law Society of Lesotho v Ramodibedi (Constitutional Case No 1 of 2003) [2003] LSHC 89 (15 August 2003) Maqutu $\mathrm{J}$ at para 7 shared a similar view thus, "[i]t seems to me that the present constitutional dispensation is a continuation of a tradition that Lesotho has inherited from Britain. Time and time again when constitutional problems arise Britain is our first reference point".

$59 \quad$ Macartney 1970 Parliamentary Affairs 121.

$60 \quad$ Khaketla case 19.

61 D'Oliveira 1986 Africa Insight 6.

62 Electoral Amendment Act 10 of 1984.

63 Human Rights Act 24 of 1983. It is important to note that from the time that the 1966 (independence) Constitution was suspended in 1970, the Human Rights Act (1983) was the only law that embodied high constitutional norms against which the actions of government could be measured. Khaketla case 19. 
Foreign Affairs. ${ }^{65}$ However, the tenability of the principle enunciated in these two cases was convincingly refuted by Mahomed JA in the Court of Appeal decision in Attorney General $v$ Swissbourgh Diamond Mine. ${ }^{66}$ The Court of Appeal said: 67

The doctrine of parliamentary sovereignty, which had its origin in English law ... never properly became part of the common law of South Africa or Lesotho and that it had merely been imposed and maintained as a matter of political expediency .... .

On the legislative process, the 1993 Constitution of Lesotho, like most Commonwealth constitutions, ${ }^{68}$ provides that subject to the Constitution each House of Parliament may regulate its own procedure and may in particular make rules for the orderly conduct of its own proceedings. ${ }^{69}$ The parliament in Lesotho is bicameral. ${ }^{70}$ However, a bill originates in the National Assembly. ${ }^{71}$ Due to its ancestral relationship with the British parliamentary practice, the parliamentary procedure is shielded from judicial review through an ouster clause. ${ }^{72}$ Section $80(5)$ of the Constitution provides that "a certificate given by the Speaker of the National Assembly under this section shall be conclusive for all purposes and shall not be questioned in any court". ${ }^{73}$ The opinion of the judiciary in Lesotho is divided about the legal effect of this clause. In the case of Development for Peace

Tsang case 145. The court therein decreed that the "[t]he law of Lesotho is the same as the law of England and Republic of South Africa. An Act of Parliament is supreme. Once it has been properly passed by the Military Council the courts must give effect to it".

$66 \quad$ Swissbourgh Diamond Mine case 214.

67 Swissbourgh Diamond Mine case 225.

68 For the analysis of the Zimbabwean Constitution on the similar provisions see the case of Biti v Minister Justice Legal and Parliamentary Affairs 2002 ZWSC 9 (27 February 2002).

69 Section 81(1) of the Constitution of Lesotho. S 81(3) provides for the power to confer privileges thus,"[p]arliament may, for the purpose of the orderly and effective discharge of the business of the two Houses, make provision for the powers, privileges and immunities of those Houses and the Committees and the members thereof (including any person who is President or Vice-President or Speaker or Deputy Speaker of either House, having been elected from among persons who were not members thereof."

70 Section 54 of the Constitution of Lesotho.

71 Section 78(2) of the Constitution of Lesotho.

72 The clause is apparently not the only constitutional clause under the 1993 Constitution of Lesotho. Also see s 91(5), which provides that "... where the King is required by this Constitution to act in accordance with the advice of any person or authority, the question whether he has received or acted in accordance with such advice shall not be enquired into in any court."

73 This clause is common in many constitutions that follow the classic parliamentary practice. Salva 1963 Philip LJ 477. 
Education $v$ Speaker of the National Assembly ${ }^{74}$ the Constitutional Court ${ }^{75}$ refused to penetrate the clause to investigate whether in the enactment of the Human Rights Commission Act $^{76}$ the National Assembly complied with section $80(3)$ of the Constitution. The court dismissed the application and reasoned that: ${ }^{77}$

It should at all times be recognised that the Parliament of Lesotho has the power under the Constitution to make laws and to regulate its own procedure and processes and in particular to make rules for the orderly conduct of its own proceedings. This is a fundamental aspect of its legislative power vested in it by the Constitution and one that is indeed expressive of the doctrine of 'separation of powers'.

However, in the most recent decision in Mokhothu $v$ Speaker of the National Assembly, ${ }^{78}$ the same court categorically demonstrated its willingness to pierce through the ouster clause if the law has been violated. In this case the applicant was deprived of his status as the official leader of opposition after his party lost one member of parliament to the government. The speaker did this despite the fact that the other opposition parties had written to assure the speaker that they supported the first applicant as the official leader of opposition. The decision of the speaker was made by way of a ruling on a point of order that was raised by the Minister of Forestry. ${ }^{79}$ The

$74 \quad$ Development for Peace Education v Speaker of the National Assembly (No 5/2016) [2017] LSHC 5 (13 March 2017) (hereafter the Development for Peace Education case).

It is important to note that the Constitution of Lesotho does not establish a superior court called "the Constitutional Court". It is the High Court that has original jurisdiction to adjudicate over constitutional matters. However, the phrase the "Constitutional Court" began to be heard in the year 2000 after the adoption of the Constitutional Litigation Rules (Legal Notice 194 of 2000). The rules provide for a special procedure for constitutional matters. The Court of Appeal in the case of Chief Justice $v$ Law Society (C of A CIV NO/59/2011) [2012] LSCA 3 (27 April 2012) confirmed that when the High Court is sitting in terms of Constitutional Litigation Rules, the bench must be constituted by no less than three judges.

76 Human Rights Commission Act 2 of 2016.

77 Development for Peace Education case para 21.

78 Mokhothu $v$ Speaker of the National Assembly (Constitutional Case No 20/2017) 2017 LHC 20 (21 February 2018) (hereafter the Mokhothu case). Also in the case of All Basotho Convention v Speaker of the National Assembly (CIV/APN/406/2016) [2017] LSHC 1 (23 February 2017), the court declared that the Speaker did not have the power to make a pronouncement of the vacancy of a seat of Parliament. The Speaker in casu had declared vacancies in the National Assembly in a situation where certain members of parliament failed to attend the necessary number of sittings of the National Assembly as provided for in s 60(1)(g) of the Constitution. The case did not deal with the review of the internal proceedings of parliament per se, but it is one of the rare occasions in Lesotho where the judiciary stood firm and reviewed the decisions of parliament or its officials.

79 The Minister rose on a point order and said, "... I consider that one quarter of this House's Membership consists of 30 Members, what then with the recent drastic changes (i.e. floor-crossing)? To me, there is no political party with the $1 / 4$ (30 
Speaker's defence was that the ruling was an internal proceeding and that it was protected by privilege as codified by the ouster clause in section $80(3)$ of the Constitution. The court rejected the argument and upheld the application. It reasoned that: 80

Parliament is a creature of the Constitution. It is conferred with powers under section 81(1) to make rules to regulate its own procedure and orderly conduct in each House. That power is 'subject to the provisions of this Constitution. These quoted words indicate that the rule-making power of Parliament is not absolute but limited by the provisions of the Constitution. Thus, this Court has jurisdiction and power to declare the Speaker's rulings, rules, practice or usage of Parliament invalid if inconsistent with or violative of any part of the Constitution.

Here the court is trying to align itself with the modern interventionist approach to internal parliamentary proceedings. However, the most inhibiting aspect of Lesotho's constitutional law is that the Constitution protects the internal proceedings of parliament through a conclusive certificate of the Speaker of the National Assembly. Although the court makes a generalised statement in Mokhothu's case that the court will declare the "Speaker's rulings, rules, practice or usage of Parliament invalid if inconsistent with or violative of any part of the Constitution", it did not address itself to the effect of section 80(3) of the Constitution, which embodies the ouster of the courts. ${ }^{81} \mathrm{~A}$ dedicated interpretation of this section by the court could have helped shape the jurisprudence around the clause, and to definitively overrule the previous decisions which follow the non-interventionist approach. ${ }^{82}$

\section{Review of legislative process in South Africa}

Prior to the 1994 politico-legal transition, ${ }^{83}$ South African constitutional law was overshadowed by parliamentary sovereignty. ${ }^{84}$ The general attitude of the courts was that the courts would ordinarily not overturn the work of

Members) majority to qualify for the Official Leader of the Opposition. Can you kindly guide us on the proper procedure in this regard?"

Mokhothu case para 14. For this approach the Court relied on the Namibian Supreme Court decision in Federal Convention of Namibia v Speaker, National Assembly of Namibia 19941 SA 177 (Nra HC) and the South African Supreme Court Decision in the De Lille case. It should be noted that this is a constitutional ouster clause; not an ordinary statutory ouster clause. See the Nigerian case of The Resident, Badan Province $v$ Memudu Lagunju 14 WACA 549.

83 Mureinik 1994 SAJHR 31; Ramaite Role of the Judiciary 150.

$84 \quad$ Poovalingam $v$ Rajbansi 19921 SA 283 (A). The court in casu admitted that there is a "close bond between [South African] law and English law on the subject of parliamentary privilege". Laubscher 1981 SALJ 529; Daniels and Brickhill 2006 Penn St Int'I L Rev 371. 
parliament. ${ }^{85}$ Both the substantive and the procedural review of parliament were ordinarily not available. However, there were exceptional occasions when the judiciary, as in England, ${ }^{86}$ used procedural impropriety as a ground for overturning an Act of parliament. ${ }^{87}$ As early as 1937 the court in the Ndlwana $v$ Hofmeyr ${ }^{88}$ case declined jurisdiction to enquire into legislation that had in effect been unprocedurally enacted. The law had been enacted by two Houses sitting together and not bi-camerally as the law prescribed. ${ }^{89}$ However the court expressly, and rather bizarrely remarked that even if the procedure had been flouted in the legislative process, "the question then is whether a Court of Law can declare that a Sovereign Parliament cannot validly pronounce its will unless it adopts a certain procedure in this case a procedure impliedly indicated as usual in the South Africa Act?"90 The court proceeded to provide the answer for the question that "Parliament, composed of its three constituent elements, can adopt any procedure it thinks fit. The procedure express or implied in the South Africa Act is so far as Courts of Law are concerned at the mercy of Parliament like everything else." 91 In adopting this absolute non-interventionist approach the court was following the decision in $R v$ Ndobe. ${ }^{92}$ The subsequent decisions in in the Harris ${ }^{93}$ cases expressly deviated from those in the Ndlwana and Ndobe cases. The court adopted an interventionist approach where the parliament had violated the procedure laid out by the South Africa Act to enact the Separate Representation of Voters Act, 1951.94 The court unequivocally departed from Ndlwana. ${ }^{95}$ Despite the approach taken in the Harris cases, the court in Collins $v$ Minister of the Interior ${ }^{96}$ unexpectedly declined to intervene in a case where the law was passed bi-camerally when

85 Cowen 1952 MLR 282.

$86 \quad R$ (Jackson) v Attorney General [2006] 1 AC 262. See further Craig "Sovereignty of the United Kingdom Parliament" 359; Eekelaar 1997 LQR 185.

87 Harris $v$ Minister of the Interior 19522 All SA 400 (A) and Collins $v$ Minister of the Interior 19571 All SA 227 (A) (hereafter the Collins case). Ndlwana $v$ Hofmeyr 1937 AD 229 (hereafter the Ndlwana case) 237. See also Griswold 1953 Harv L Rev 864.

89 Section 35(1) of the Union of South African Act, 1909.

$90 \quad$ Ndlwana case 238.

$91 \quad$ Ndlwana case 238.

$92 \quad R v$ Ndobe 1930 AD 484.

93 Harris $v$ Minister of the Interior 19522 All SA 400 (A); Minister of the Interior $v$ Harris 19524 All SA $376(A)$. Separate Representation of Voters Act 46 of 1951. Also see Griswold 1953 Harv L Rev 864.

In Harris $v$ Minister of the Interior 19522 All SA 400 (A) 423 the court said, "The question now arises whether this Court ought to depart from Ndlwana's case. Earlier in this judgment I have referred to a number of cases which show that there may be circumstances in which the Court ought to depart from its previous decision. There is no doubt in my mind that this is essentially a case where this Court is bound, on it shaving been shown that its previous decision was wrong, to depart from that decision". 
it was supposed to be passed uni-camerally in terms of the South African Act; and its purpose was clearly the same purpose which the parliament unsuccessfully sought to attain in the Harris case. The court ruled that "[i]f a Legislature has plenary power to legislate on a particular matter no question can arise as to the validity of any legislation on that matter and such legislation is valid whatever the real purpose of that legislation is". ${ }^{97}$

The 1996 Constitution of South Africa seems to have made a clear break from a past which was based on parliamentary sovereignty and accepted a new system based on constitutionalism. ${ }^{98}$ While the Constitution seems to have retained the common law notion of parliamentary privilege, ${ }^{99}$ it has also made two fundamental modifications of the concept. The first one is that it has removed the ouster clause that usually precludes judicial scrutiny of the legislative process. The second one is that the common law on parliamentary privilege has been constitutionalised; thus, any aspect of the concept which has not been codified in the Constitution is not permissible. ${ }^{100}$ This approach was adopted in the landmark decision in The Speaker of the National Assembly v Patricia De Lille. ${ }^{101}$ The case involved the suspension of a member of parliament through a resolution of the National Assembly on the basis that her speech in parliament was "un-parliamentary". She had alleged that her party had information pertaining to twelve members of the "other side of the House (the ANC) who had been accused of having been spies for the apartheid regime". She was suspended for fifteen parliamentary working days. She challenged the suspension. The Speaker, in her argument, wanted to claim the protection of parliamentary privilege. The court rejected that line of argument and said that the "enquiry must crucially rest on the Constitution of the Republic of South Africa... [not] a tortuous process of discovery of some obscure rule in English Parliamentary law and custom justifying the suspension of a member of Parliament." 102 In the end, Mahomed CJ found that "there is nothing which provides any constitutional authority for the Assembly, to punish any member of the Assembly, for making any speech, through an order suspending such member from the proceedings of the Assembly". ${ }^{103}$

$97 \quad$ Collins case 231.

98 Mureinik 1994 SAJHR 31.

99 Section 57 of the Constitution provides that: "(1) The National Assembly may - (a) determine and control its internal arrangements, proceedings and procedures; and (b) make rules and orders concerning its business, with due regard to representative and participatory democracy, accountability, transparency and public involvement". Also see $\mathrm{s} 58$.

100 On the relationship between common law and the Constitution in South Africa, see Friedman 2014 SAJHR 63.

101 See De Lille case.

102 De Lille paras 14 and 20.

103 De Lille para 29. 
The approach of the court in Patricia De Lille became the trailblazer. In the Doctors for Life International case, the Constitutional Court reiterated that there is no express constitutional provision that precludes a court in South African from intervening in the legislative process. The court brought in the notion of the "sensitive balance", however. It said:104

\begin{abstract}
What courts should strive to achieve is the appropriate balance between their role as the ultimate guardians of the Constitution and the rule of law including any obligation that Parliament is required to fulfil in respect of the passage of laws, on the one hand, and the respect which they are required to accord to other branches of government as required by the principle of separation of powers, on the other hand.
\end{abstract}

This approach is slightly different from the one suggested in the UDM case of non-intervention "save in extreme cases". ${ }^{105}$ With the approach in South Africa now fairly well established that the courts can intervene in the legislative process, the courts are now grappling with the notion of the "sensitive balance" as provided for in the Doctors for Life International case. The Constitution and the rule of law occupy one side of the scale, while the separation of powers occupies the other. The court grappled with this balance in the Mazibuko case. This is the case that concerned the tabling of a motion of no confidence in the President. The applicant, as a leader of the opposition in Parliament, gave notice in the National Assembly of a motion of no confidence in the President in terms of section 102(2) of the Constitution. The motion was frustrated by parliament committees so that it was ultimately not tabled before the National Assembly. The applicant then approached the High Court on an urgent basis, seeking an order directing the Speaker to take the necessary steps to ensure that the motion of no confidence was debated and voted upon as a matter of urgency. The vexed question was whether a court could direct a Speaker to place a motion on a parliamentary roll when there was no consensus in the committees. The court was sharply divided ${ }^{106}$ over this question. The majority judgement authored by Moseneke DCJ found that the speaker does not have such residual powers, ${ }^{107}$ but disagreed with the respondents' argument that "[i]f

104 See Doctors for Life International case 1427.

105 UDM case para 31. The "non-intervention save in extreme cases" approach does not seem to be an approach different from the sensitive balance approach, though. The only difference is that in the former, the scale is tilted in favour of nonintervention, while in the latter it is balanced.

106 The court comprised 10 justices and the division was in the ratio of 6:4. The majority comprised Moseneke DCJ with Froneman, Khampepe, Nkabinde, Skweyiya and Van der Westhuizen JJ concurring, while the minority comprised Jafta J, Mogoeng CJ, Zondo J and Mhlantla AJ.

107 The court seems to have attempted the balancing exercise thus (para 31 of the Mazibuko case): "Section 57(1) of the Constitution vests in the Assembly the power to determine and control its internal arrangements, proceedings and procedures, and it may make rules and orders concerning its business. Should the Speaker choose to make a ruling on the business of the Assembly, it would always be subject to the 
there is no political agreement on the scheduling of the motion, then that is the end of the matter and the motion will not be scheduled or debated."108 He agreed with the court a quo (the High Court) that: ${ }^{109}$

\begin{abstract}
... a vital constitutional entitlement to move a motion of no confidence in the President cannot be left to the whim of the majority or minority in the Programme Committee or any other committee of the Assembly. It would be inimical to the vital purpose of section 102(2) to accept that a motion of no confidence in the President may never reach the Assembly except with the generosity and concurrence of the majority in that Committee.
\end{abstract}

The court in turn invalidated Chapter 12 of the Rules of the National Assembly to the extent that it does not provide for enforcement of the right to exercise the power to have a motion of no confidence in the President "scheduled for a debate and voted upon in the National Assembly within a reasonable time, or at all."110 The minority judgement held a different view. In fact, it invoked the political question doctrine ${ }^{111}$ wherein Jafta J, writing for the minority, contended that "[p]olitical issues must be resolved at a political level. Our courts should not be drawn into political disputes, the resolution of which falls appropriately within the domain of other fora established in terms of the Constitution."112

The "sensitive balance" seems to be haunting the courts in South Africa, and it continues to sharply divide judicial and scholarly opinion. ${ }^{113}$ The most recent decision on the review of parliamentary process where the division of judicial opinion further manifested itself was in the case of Economic Freedom Fighters $v$ Speaker of the National Assembly. ${ }^{114}$ The central question in this case was whether the National Assembly had breached its obligation to put in place "mechanisms and a process" for the

overriding authority of the Assembly, which is the ultimate master of its own process, subject to the usual caveat that its processes are consistent with the Constitution and the law."

108 Mazibuko case para 54.

$109 \quad$ Mazibuko case para 57.

$110 \quad$ Mazibuko case para 88.

111 The doctrine has its roots in American constitutional law. It provides that certain constitutional questions are best left to the elected branches of government and are therefore non-justiciable. Mhango 2014 PELJ 2704. Also see Barkow 2002 Colum L Rev 237; Choper 2004 Duke LJ 1457.

112 Mazibuko case para 83. The minority was persuaded by the dictum in the court a quo Mazibuko v Sisulu 20134 SA 243 (WCC) 256EH thus, "There is a danger in South Africa, however, of the politicisation of the judiciary, drawing the judiciary into every and all political disputes as if there is no other forum to deal with a political impasse relating to policy or disputes which clearly carry polycentric consequences beyond the scope of adjudication."

113 See the cases United Democratic Movement v Speaker, National Assembly 20175 SA 300 (CC). Also see the EFF I case para 93; Cachalia 2015 NYL Sch L Rev 379.

114 Economic Freedom Fighters $v$ Speaker of the National Assembly 20183 BCLR 259 (CC) (hereafter the EFF /l case). 
implementation of section 89 of the Constitution. The section provides for the impeachment of the President. ${ }^{115}$ As in the Mazibuko case, the question sharply divided the court by a vote of 7:4. The majority judgement was authored by Jafta $\mathrm{J}$, who found that "section 89(1) implicitly imposes an obligation on the Assembly to make rules specially tailored for an impeachment process contemplated in that section."116 The court in turn found that the National Assembly had violated that obligation, and directed it to make rules that would facilitate the implementation of section 89 of the Constitution. The minority vehemently disagreed that the court had any role to play in directing the National Assembly to make rules. Mogoeng CJ, concurring in the minority judgement, called the majority judgment "a textbook case of judicial overreach - a constitutionally impermissible intrusion by the Judiciary into the exclusive domain of Parliament."117 The minority judgment's chief argument was that the principle of the separation of powers prohibits the court from going so far as to tell the parliament to make rules.

This dichotomy in the judicial approach is the manifestation of the stage at which the development of the parliament-judiciary relationship has reached in South Africa. The country is grappling with the "sensitive balance". The approach seems to be developing and firming up on a case-by-case basis.

\section{Conclusion}

This paper set out to investigate the judicial review of the legislative process in Lesotho, the principal question being the extent to which superior courts in Lesotho are able to review the internal processes of parliament. Having thus found, the paper sought to establish whether the South African jurisprudence on the subject can provide lessons for Lesotho. It has become apparent from the foregoing discussion that the two countries have different approaches to the judicial review of internal parliamentary processes. Due largely to the influence of British tradition, Lesotho still subscribes to the

115 Section 89 of the Constitution provides: "(1) The National Assembly, by a resolution adopted with a supporting vote of at least two thirds of its members, may remove the President from office only on the grounds of - (a) a serious violation of the Constitution or the law; (b) serious misconduct; or (c) inability to perform the functions of office. (2) Anyone who has been removed from the office of President in terms of subsection (1)(a) or (b) may not receive any benefits of that office, and may not serve in any public office."

116 EFF /l case para 196.

117 EFF // case para 223. The Judges in the Majority Judgement did not take the expression "text book case of judicial overreach" kindly. As a result, Jafta $\mathrm{J}$ at para 218 retorted that "... what is unprecedented is the suggestion that the construction of the section embraced by the majority here constitutes 'a textbook case of judicial overreach'. The suggestion is misplaced and unfortunate". 
classic common law approach. This is the approach that absolutely protects the "internal proceedings" of parliament from scrutiny. The approach has been taken to the constitutional level by section $80(5)$ of the Constitution of Lesotho. The section, as demonstrated above, precludes the courts from enquiring into the certificate of the Speaker confirming that the procedure in enacting a law was properly followed. The courts in Lesotho have largely remained helpless against this ouster. ${ }^{118}$ An outlier is the Mokhothu's case, in which the court sought to demonstrate that on the basis of constitutionalism and legality it can review the internal proceedings of parliament. But the Mokhothu case will scarcely become an authority for the proposition that courts can readily review internal parliamentary proceedings in Lesotho. This is because the case exists alongside the constitutional ouster clause which has not been authoritatively interpreted, as is the case in countries such as Nigeria. ${ }^{119}$

The South African approach, on the other hand, demonstrates a clear break from the approach in the pre-democratic era as epitomised by the Ndlwana and Collins cases. ${ }^{120}$ The case of De Lille is the standard bearer of the new approach, which is based on easy intervention of the courts once a constitution or some other law has been violated. The challenge with the new approach in South Africa, though, is that it vacillates between two equally important constitutional fundamentals: the notion of judicial review (based on legality) on the one hand and the separation of powers on the other. This balancing exercise has not yet stabilised. The instability is evidenced by the sharp difference in judicial opinion on the subject as manifested in cases such as UDM and the two EFF cases. ${ }^{121}$ It would seem that the country is building jurisprudence on this new issue on a case-bycase basis.

In the circumstances, it is recommended that Lesotho should introduce a paradigmatic shift similar to that made in South Africa. The first step would be to abolish all vestiges of parliamentary sovereignty in Lesotho; and to remove the ouster clause from section $80(5)$ of the Constitution. Consequently, the common law notion of parliamentary privilege should be recast within the context of the modern idea of constitutionalism.

\footnotetext{
118 Generally see the Development for Peace Education and Transformation Resource Centre case.

119 See the Nigerian approach to constitutional ouster clauses in cases like The Resident, Badan Province v Memudu Lagunju 14 WACA 549; Governor-in-Council, Western Region of Nigeria $v$ Jonathan Oshunlaja (1961) 1 SCNLR 303; Prince Ademuluyi v Brig RA Adebayo (1968) 2 All NLR 272; Lakanmi v Attorney General, West (1971) 1 UILR 201.

120 Wade 1957 SALJ 160; Dlamini 1988 SALJ 470.

121 For a critique on the seeming judicial activism in relation to the legislature in South Africa, see Cachalia 2015 NYL Sch L Rev 379.
} 


\section{Bibliography}

\section{Literature}

Allen and Thomson Cases and Materials

Allen $\mathrm{M}$ and Thomson $\mathrm{M}$ Cases and Materials on Constitutional and Administrative Law $9^{\text {th }}$ ed (Oxford University Press Oxford 2008)

Andrews Works of James Wilson

Andrews J The Works of James Wilson (Callaghan Chicago 1896)

Arenson 1996 Deakin L Rev

Arenson KJ "Rejection of the Power of Judicial Review in Britain" 1996 Deakin L Rev 37-54

Barber 2011 ICON

Barber NW "The Afterlife of Parliamentary Sovereignty" 2011 ICON 144154

Barkow 2002 Colum L Rev

Barkow RE "More Supreme than Court: The Fall of the Political Question Doctrine and the Rise of Judicial Supremacy" 2002 Colum L Rev 237-336

Barroso da Graca 2018 UCL JL and J

Barroso da Graca LO "Judicial Review of the Legislative Process in Brazil" 2018 UCL JL and J 55-81

Bar-Siman-Tov 2011 BU L Rev

Bar-Siman-Tov I "The Puzzling Resistance to Judicial Review of the Legislative Process" 2011 BU L Rev 1915-1974

Beardsley $1970 \mathrm{~J}$ Afr $L$

Beardsley JE "The Common Law in Lesotho" 1970 J Afr L 198-202

Bickel Least Dangerous Branch

Bickel AM The Least Dangerous Branch: The Supreme Court at the Bar of Politics (Yale University Press New Haven 1986)

Bradley and Ewing Constitutional and Administrative Law

Bradley AW and Ewing KD Constitutional and Administrative Law $12^{\text {th }}$ ed (Longman London 1997)

Cachalia 2015 NYL Sch L Rev

Cachalia F "Judicial Review of Parliamentary Rulemaking: A Provisional Case for Restraint" 2015 NYL Sch L Rev 379-408 
Cella 1968 Suffolk $U L$ Rev

Cella AJ "The Doctrine of Legislative Privilege of Freedom of Speech and Debate: Its Past, Present and Future as a Bar to Criminal Prosecutions in the Courts" 1968 Suffolk U L Rev 1-43

Choper 2004 Duke LJ

Choper JH "The Political Question Doctrine: Suggested Criteria" 2004 Duke LJ 1457-1524

Cowen 1952 MLR

Cowen DV "Legislature and Judiciary: Reflections on the Constitutional Issues in South Africa: Part I" 1952 MLR 282-296

Craig "Sovereignty of the United Kingdom Parliament"

Craig PP "Sovereignty of the United Kingdom Parliament after Factortame" in Loveland ID (ed) Constitutional Law (Routledge London 2018) 359-394

Daniels and Brickhill 2006 Penn St Int'l L Rev

Daniels $\mathrm{RN}$ and Brickhill $\mathrm{J}$ "The Counter-majoritarian Difficulty and the South African Constitutional Court" 2006 Penn St Int'I L Rev 371-404

De Smith New Commonwealth and its Constitutions

De Smith SA The New Commonwealth and its Constitutions (Stevens London 1964)

Delaney 2013 Nw U L Rev

Delaney EF "Judiciary Rising: Constitutional Change in the United Kingdom" 2013 Nw U L Rev 543-606

Dicey Study of the Law of the Constitution

Dicey AV Introduction to the Study of the Law of the Constitution $8^{\text {th }}$ ed (Macmillan London 1915)

Dlamini 1988 SALJ

Dlamini C "The Senate Case Revisited" 1988 SALJ 470-478

D'Oliveira 1986 Africa Insight

D'Oliveira J "Lesotho: 20 Years of Iron-fisted Rule Comes to an End" 1986 Africa Insight 6-9

Eekelaar 1997 LQR

Eekelaar J "The Death of Parliamentary Sovereignty: A Comment" 1997 LQR 185-187 
Friedman 2014 SAJHR

Friedman $F$ "The South African Common Law and the Constitution: Revisiting Horizontality" 2014 SAJHR 63-88

Goldsworthy Parliamentary Sovereignty

Goldsworthy J Parliamentary Sovereignty: Contemporary Debates (Cambridge University Press Cambridge 2010)

Griswold 1953 Harv L Rev

Griswold EN "The Demise of the High Court of Parliament in South Africa" 1953 Harv L Rev 864-872

Harel and Shinar 2012 ICON

Harel A and Shinar A "Between Judicial and Legislative Supremacy: A Cautious Defense of Constrained Judicial Review" 2012 ICON 950-975

Hatsell Precedents of Proceedings in the House of Commons

Hatsell J Precedents of Proceedings in the House of Commons: Relating to Members, Speaker, etc (Hansard London 1818)

Hoexter Administrative Law

Hoexter C Administrative Law in South Africa (Juta Cape Town 2012)

Jain $1967 \mathrm{JILI}$

Jain DC "Judicial Review of Parliamentary Privileges: Functional Relationship of Courts and Legislatures in India" 1967 JILI 205-222

Khaketla Lesotho 1970

Khaketla BM Lesotho 1970: An African Coup under the Microscope (University of California Press Berkeley 1972)

Kretzmer 1988 Tel Aviv U Stud L

Kretzmer D "Judicial Review of Knesset Decisions" 1988 Tel Aviv U Stud L 95-156

Laubscher 1981 SALJ

Laubscher PJ "The Foundation of Sovereignty: Parliament as a Law-making Body" 1981 SALJ 529-541

Macartney 1970 Parliamentary Affairs

Macartney WJA "African Westminster? The Parliament of Lesotho" 1970 Parliamentary Affairs 121-140

Macartney 1973 Government and Change

Macartney WJA "The Lesotho General Election of 1970" 1973 Government and Change 473-494 
May Erskine May's Treatise

May TE Erskine May's Treatise on the Law, Privileges, Proceedings and Usage of Parliament $22^{\text {nd }}$ ed (Butterworth-Heinemann London 1997)

Mhango 2014 PELJ

Mhango M "Separation of Powers in Ghana: The Evolution of the Political Question Doctrine" 2014 PELJ 2704-2744

Mureinik 1994 SAJHR

Mureinik E "A Bridge to Where? Introducing the Interim Bill of Rights" 1994 SAJHR 31-48

Navot 2006 Israel L Rev

Navot S "Judicial Review of the Legislative Process" 2006 Israel L Rev 182247

'Nyane 2014 Lesotho LJ

'Nyane H "Development of Constitutional Democracy: 20 Years of the Constitution of Lesotho" 2014 Lesotho LJ 59-86

'Nyane "Development of the Constitution of Lesotho"

'Nyane $\mathrm{H}$ "Development of the Constitution of Lesotho since Independence: The Critique of Westminster Design in Lesotho" in Tsikoane T (ed) Lesotho at Fifty Years of Independence: Aspects of Chequered Development Journey (Morija Printing Works Morija 2018) 121-139

Okpaluba 2015 CILSA

Okpaluba C "Can a Court Review the Internal Affairs and Processes of the Legislature? Contemporary Developments in South Africa" 2015 CILSA 183-218

Okpaluba and Mhango 2017 LDD

Okpaluba C and Mhango M "Between Separation of Powers and Justiciability: Rationalising the Constitutional Court's Judgement in the Gauteng E-tolling Litigation in South Africa" 2017 LDD 1-24

Palmer $1969 \mathrm{~J}$ Afr L

Palmer VV "The Common Law in Lesotho" 1969 J Afr L 127-144

Palmer and Poulter Legal System of Lesotho

Palmer VV and Poulter SM The Legal System of Lesotho (Michie Charlottesville, Va 1972)

Ramaite Role of the Judiciary

Ramaite MS The Role of the Judiciary in a Modern State with a Tradition of Legislative Supremacy (LLD-thesis University of South Africa 1996) 
Sakoane 2000 Lesotho LJ

Sakoane $S$ "The Latimer House Guidelines on Preserving the Independence of Parliamentarians: Constitutional and Legal Guarantees in Lesotho" 2000 Lesotho LJ 39-69

Salva 1963 Philip LJ

Salva EM "Parliamentary Freedom of Speech" 1963 Philip LJ 477-511

Steele 2012 Nott LJ

Steele J "Immunity of Parliamentary Statements" 2012 Nott LJ 43-53

Taiwo 2009 Malawi LJ

Taiwo EA "Judicial Review of the Impeachment Procedure in Nigeria" 2009 Malawi LJ 236-272

Tucker 2011 OJLS

Tucker A "Uncertainty in the Rule of Recognition and in the Doctrine of Parliamentary Sovereignty" 2011 OJLS 61-88

Wade 1957 SALJ

Wade $\mathrm{H}$ "The Senate Act Case and the Entrenched Sections of the South Africa Act" 1957 SALJ 160-166

Waldron 2006 Yale LJ

Waldron $\mathrm{J}$ "The Core of the Case against Judicial Review" 2006 Yale LJ 1346-1406

Yankwich $1950 \cup P a L R e v$

Yankwich LR "Immunity of Congressional Speech: Its Origin, Meaning and Scope" 1950 U Pa L Rev 960-977

\section{Case law}

All Basotho Convention $v$ Speaker of the National Assembly (CIV/APN/406/2016) [2017] LSHC 1 (23 February 2017)

Attorney General v Mopa LAC (2000-2004) 427

Attorney General v Swissbourgh Diamond Mine LAC (1995-1999) 214

Biti v Minister Justice Legal and Parliamentary Affairs 2002 ZWSC 9 (27 February 2002)

British Railways Board v Pickin [1974] 1 All ER 609 
Chalatse $v$ The Acting Chief Justice (C of A CIV NO/63/2014) [2015] LSCA 19 (7 August 2015)

Chief Justice $v$ Law Society (C of A CIV NO/59/2011) [2012] LSCA 3 (27 April 2012)

Collins v Minister of the Interior 19571 All SA 227 (A)

Development for Peace Education v Speaker of the National Assembly (No 5/2016) [2017] LSHC 5 (13 March 2017)

Doctors for Life International $v$ Speaker of the National Assembly 20066 SA 416 (CC)

Dombrowski v Eastland 387 US 82 (1967)

Economic Freedom Fighters $v$ Speaker of the National Assembly 20163 SA 580 (CC)

Economic Freedom Fighters $v$ Speaker of the National Assembly 20183 BCLR 259 (CC)

Edinburgh \& Dalkeith Railway v Wauchope (1842) $8 \mathrm{Cl}$ and F710

Executive Council of the Western Cape Legislature $v$ President of the Republic of South Africa 199510 BCLR 1289 (CC)

Federal Convention of Namibia v Speaker, National Assembly of Namibia 19941 SA 177 (Nra HC)

Field v Clark 143 US 649 (1892)

Governor-in-Council, Western Region of Nigeria $v$ Jonathan Oshunlaja (1961) 1 SCNLR 303

In re Certification of South Africa 19964 SA 744 (CC)

Johannesburg Consolidated Investment Co v Johannesburg Town Council 1903 TS 111

Harris v Minister of the Interior 19522 All SA 400 (A)

Khaketla $v$ The Honourable Prime Minister (CIV/APN/145/85) [1985] LSCA 118 (24 July 1985)

Kilbourn v Thompson 103 US 168 (1881) 
Lakanmi v Attorney General, West (1971) 1 UILR 201

Law Society of Lesotho v Ramodibedi (Constitutional Case No 1 of 2003) [2003] LSHC 89 (15 August 2003)

Lee v Bude \& Torrington Railway Co 1871 LR 6 CP 577

Marbury v Madison 5 US (1 Cranch) 137 (1803)

Mazibuko v Sisulu 20134 SA 243 (WCC)

Mazibuko v Sisulu 201311 BCLR 1297 (CC)

Minister of the Interior v Harris 19522 All SA 400 (A)

Minister of the Interior v Harris 19524 All SA 376 (A)

Mokhothu $v$ Speaker of the National Assembly (Constitutional Case No 20/2017) 2017 LHC 20 (21 February 2018)

Ndlwana v Hofmeyr 1937 AD 229

Peta $v$ Minister of Law, Constitutional Affairs and Human Rights (CC 11/2016) [2018] LSHC 3 (18 May 2018)

President of the Republic of South Africa $v$ United Democratic Movement 20031 SA 472 (CC)

Prince Ademuluyi v Brig RA Adebayo (1968) 2 All NLR 272

Poovalingam v Rajbansi 19921 SA 283 (A)

Powell v McCormack 395 US 486 (1969)

$R$ (Jackson) v Attorney General [2006] 1 AC 262

$R v$ Ndobe 1930 AD 484

Raphuthing $v$ Chairman of the Disciplinary Hearing C of A (CIV) 45/2014 [2015] LSCA 2 (7 August 2015)

S v Makwanyane 19956 BCLR 665 (CC)

Sarid v Knesset Speaker (1981) 36 (2) PD 198

Speaker of the National Assembly v De Lille 19994 SA 863 (SCA) 
Tenney $v$ Brandhove 341 US 367 (1951)

The Resident, Badan Province v Memudu Lagunju 14 WACA 549

Transformation Resource Centre $v$ Speaker of the National Assembly (Constitutional Case No 4 of 2017) [2017] LSHC 23 (30 November 2017)

Tsang v Minister of Foreign Affairs 1993-94 LLR-LB 45 (HC)

United Democratic Movement v Speaker, National Assembly 20175 SA 300 (CC)

United States v Johnson 383 US 169 (1966)

\section{Legislation}

Basutoland Constitution, 1959

Basutoland Constitution, 1965

Bill of Rights (1689) (England)

Constitution of Lesotho, 1966

Constitution of Lesotho, 1993

Constitution of the Republic of South Africa, 1996

Constitutional Litigation Rules (Legal Notice 194 of 2000)

Electoral Amendment Act 10 of 1984

Human Rights Act 24 of 1983 (UK)

Human Rights Commission Act 2 of 2016 (Lesotho)

Separate Representation of Voters Act 46 of 1951

Union of South Africa Act, 1909

United Kingdom Parliament Act, 1911

United Kingdom Parliament Act, 1949

\section{List of Abbreviations}

BU L Rev

Boston University Law Review 
CILSA

Colum L Rev

Deakin L Rev

Duke LJ

Harv L Rev

ICON

Israel L Rev

J Afr L

JILI

LDD

Lesotho LJ

LQR

Malawi LJ

MLR

NYL Sch L Rev

OJLS

PELJ

Penn St Int'I L Rev

Philip LJ

Nott LJ

Nw U L Rev

SAJHR

SALJ

Suffolk U L Rev

Tel Aviv U Stud L

Va L Rev

U Pa L Rev

UCL JL and J

Yale LJ
Comparative and International Law Journal of Southern Africa

Columbia Law Review

Deakin Law Review

Duke Law Journal

Harvard Law Review

International Journal of Constitutional Law

Israel Law Review

Journal of African Law

Journal of the Indian Law Institute

Law, Democracy and Development

Lesotho Law Journal

Law Quarterly Review

Malawi Law Journal

Modern Law Review

New York Law School Law Review

Oxford Journal of Legal Studies

Potchefstroom Electronic Law Journal

Penn State International Law Review

Philippine Law Journal

Nottingham Law Journal

Northwestern University Law Review

South African Journal on Human Rights

South African Law Journal

Suffolk University Law Review

Tel Aviv University Studies in Law

Virginia Law Review

University of Pennsylvania Law Review

University College London Journal of Law and Jurisprudence

Yale Law Journal 